\title{
Micro, Meso and Macro Levels of Social Analysis
}

\author{
Sandro Serpa ${ }^{1}$, Carlos Miguel Ferreira ${ }^{2}$ \\ ${ }^{1}$ University of the Azores, Faculty of Social and Human Sciences, Department of Sociology; Interdisciplinary Centre of \\ Social Sciences - CICS.UAc/CICS.NOVA.UAc; Interdisciplinary Centre for Childhood and Adolescence - NICA - UAc, \\ Portugal \\ ${ }^{2}$ Interdisciplinary Centre of Social Sciences-CICS.NOVA, Polytechnic Institute of Castelo Branco, Estoril Higher \\ Institute for Tourism and Hotel Studies, 1069-061 Lisbon, Portugal \\ Correspondence: Sandro Serpa, University of the Azores, Faculty of Social and Human Sciences, Department of \\ Sociology, Ponta Delgada, Azores, Portugal.
}

Received: April 9, 2019

Accepted: April 18, $2019 \quad$ Available online: April 22, 2019

doi:10.11114/ijsss.v7i3.4223

URL: https://doi.org/10.11114/ijsss.v7i3.4223

\begin{abstract}
Micro, meso and macro are levels or scales that can and may be mobilised in social analysis. This paper aims to contribute to the reflection and discussion, in particular, of the use of the meso level in the apprehension of social reality, in its potential advantages and disadvantages. For this purpose, a document collection and selection was carried out. Furthermore, the authors' experience in teaching and research in social sciences, especially in the area of Sociology, was also used. This analytical exercise allows concluding that the meso-social level is mobilised in some perspectives, focusing in a privileged way on the group or the organisation as a structure and intermediate process between the other two levels. As for implications, it may be asserted that the meso level only has heuristic capabilities in the interpretation of a particular social context if the other two levels are not neglected in the analysis.
\end{abstract}

Keywords: micro, meso, macro, levels of social analysis, sociology, social sciences

\section{Introduction}

The articulation between the micro and macrosocial levels has been one of the most discussed and problematized dimensions in social theory, in general, since the beginnings of the establishment of social sciences and this discussion still maintains in the contemporary world (Wiley, 1988; Sell, 2016; Ibáñez, 1997; Pyyhtinen, 2017).

The same applies to Sociology, as a science that "studies the (dis)order of the social world, and that deals with interactions, what results from interaction and has implications in this interaction between human beings, such as objects, practices, representations and values, inserting them into their social context" (Serpa \& Ferreira, 2018, p. 841).

In the specific case of Sociology, this macro-micro connection did and still does generate much discussion (Morais, \& Ratton Jr., 2005). As Rocher (1989) points out, "from the narrowest and most elementary layer of social behaviours, that of interaction between two persons, we progressively extended our perspective to social groups" (p. 65). Likewise, Pires (2012a) sustains that "Social order is embodied in patterns of social relationships. These patterns are observable in multiple domains and at different scales, in the similarities of individual behaviours as in the regularities of encounters between human agents, in the establishment of groups and organisations as in the functioning of institutions and in the distribution of social resources" (p. 40).

This same macro-micro connection underpins, in part, the fact that Sociology is a pluri-paradigmatic science given the different perspectives that emerge in the attempt to articulate these two dimensions (Serpa, 2017; Ferreira \& Serpa, 2017; Javeau, 1998; Serpa, 2018; Serpa \& Ferreira, 2018; Borup, Brown, Konrad, \& Van Lente, 2006; Pyyhtinen, 2017). Ibáñez (1997) states that "The great proposals of Sociology have done nothing more than to try to explain such continuum, from different epistemological-methodological and/or ontological-descriptive points of view" (p. 172).

\section{Methods}

We aim to contribute, specifically, to the reflection and discussion of the use of the meso level, which takes on several meanings (Fine, 2012) in the understanding of reality, in its potential advantages and disadvantages. To this end, a document collection and selection was carried out in the B-ON database (Biblioteca do Conhecimento Online, n.d.). 
Furthermore, the authors' experience in teaching and research in social sciences, especially in the field of Sociology, was also mobilised.

\section{Micro and Macro Levels of Social Analysis}

As Ferreira and Serpa (2017) maintain, "Sociology has specificities, which we put forward through four framing principles, namely the need to permanently mobilise sociological imagination, be multi-paradigmatic, the need to be receptive to a heuristic interdisciplinarity, and, finally, foster reflexivity at several levels" (p. 1). The authors complement that social analysis should be "placed on a sociological perspective that is focused on the theoretical pluralism of Sociology. This pluralism seeks to articulate macro-social dynamics with local processes, allowing the linkage between subjective significances and practices, and focusing on the articulations between systems and actors, between structures and practices" (Ferreira \& Serpa, 2017, p. 3). Furthermore, Hartman (2017) also adds the "divisions between macro level perspectives on society and culture, the meso level of organizations and groups, and the micro level of individual identity, motives, and cognition" (p. 1).

In a similar sense on this pluralism, Sell (2016) states that "the macro-micro dyad can also be understood as a metatheory, inasmuch as, on the basis of this scheme, we can locate and visualise the scales and the theoretical moments involved in the dual poles of Sociology and, in addition, to locate competing or rival approaches" (p. 326).

Micro-sociology addresses the "study of human behaviour in contexts of everyday direct interaction" (Giddens, 1997, p. 883), and face-to-face interaction is a materialisation in time and space and entails, to some extent, that there are commonly shared expectations in social life (Serpa \& Ferreira, 2018).

There are numerous examples of objects whose in-depth study requires, as demonstrated, the articulation at least between the micro and the macro levels. An example is School (Serpa, 2018; Serpa \& Sá, 2019), which implies an interconnection of scale levels.

Ibáñez (1997) offers a rather enlightening picture, by stating that,

"Like Swift (and Gulliver, his creature), there are many sociologists who posit that the plots of society can be located in two different countries: that of the «dwarves» (where the smallness of the units makes the accrual of problems evident and transparent in the eyes of the great observer) and that of the «giants» (where, on the contrary, the enormous size of the participants relativises the perspective and forces them to risk open explanatory hypotheses). Needless to say, «Liliput» would be the world of the «micro» and «Brobdingnag» would be the world of the «macro». But this lazy segregation of reality and the models to access it are not only biased in their origin but are also counterproductive. [...] And it is counterproductive because it breaks with the individual-society continuum instead of starting from it, as seems reasonable if the design of a good sociological theoretical model is sought" (pp. 171 and 172).

Furthermore, Ibáñez (1997) adds that "micro-macro relationships cease to be a dual counterposition and become hypothetical poles of a scale of magnitudes, intentionalities and objective consequences of the action that crosses transversally all the orders and processes of society, as well as its theoretical summaries" (p. 180).

\section{Meso Level of Social Analysis}

According to Sell (2016), "in every sociological theory, we can recognise a minimum unit (micro) and a maximum unit (macro). Between the extremes, several other intermediate levels (meso) can also be conceived. Thus, by leaving the content of these levels suspended, the consequence is that it is the way in which each sociological current conceives the forms of articulation between the two extreme levels of the scale" (p. 326).

Meso may be seen as a look at an intermediate unit of analysis in decision-making, for example, in Health Care Decision-Making. Boateng (2013) argues that "Micro level decisions, for example, are influenced broadly by the macro level, though this is often restricted to budget-based resource allocation; there is no direct relationship between decision-makers at the macro and the micro levels. Meso-level health care decision-makers, however, exercise tremendous influence on decisions made at the micro level" (p. 136). Serpa (2016) maintains that the same may occur in organisations, insofar as

"the organisation can be seen as a complex collective unit with a formal dimension and an informal dimension in which there is interaction between (individual and collective) actors with at least a minimum of coordination and reciprocal expectations that employ more or less different roles in the pursuit of goals set internally (not necessarily with the same degree of internal sharing) and generally recognized externally (which are not necessarily the internal goals) influencing and being influenced by the environment, producing for it, over time, characteristics that are both specific and dynamic" (p. 3258).

For example, on the medicalisation of popular sanatoria, Ferreira (2007) indicates that 
"These circumstantial coalitions of interests, which are marked by two circumstantial poles (Hygiene and Public Health Movement) that raise the visibility of discourse coalitions, are seen from different, yet interdependent, scales. A macro scale which accounts for the process of social construction of tuberculosis as a social problem and the medicalisation of the tuberculosis social problem. A meso scale which analyses the progressive shift of the popular sanatorium configuration of «multipurpose asylum space» into a «healing workshop», that is, the medicalisation of the popular sanatorium understood as the triumph of a disciplinary will, but bearing in mind the postulate that institutions and their social order are explained primarily by the relationships of power that are produced and reproduced outside of it" (p. 19).

Regarding the importance of this group level (composed of primary or secondary groups) which social structures shape individuals, Fine (2012) argues that "A focus on the group - the meso-level of analysis - enriches both structural and interactional approaches, stressing shared and ongoing meaning. Groups constitute social order, just as groups are themselves constituted by that order. The examination of local action reveals how interaction orders emerge and create meanings that spread throughout a wider network" (p. 159). Fine (2012) also considers that the meso-level approach is critical to perceiving social life and order, even considering that "sociology without groups is an incomplete and thin discipline." (p. 172).

Thus, following Javeau for his excellent proposal, social relationships regard individual interactions and are framed and conditioned by the level of social relations that take place between groups structured in a given social hierarchy, and both are included on a broader scale - the frames of the social - as a social reference framework built throughout history, in its economic, political and cultural dimensions, with mutual inter-penetrations between these three levels. Social relationships materialise the production and reproduction of the other levels (Javeau, 1998) in a reciprocal influence. Social processes are continually recreated in a socially located historical time-space, and these social contacts may happen at the individual or group levels, always integrating into a wider context: "The frames, products of history, represent the «systematic» framework in which human actions unfold in their extraordinary multiplicity and diversity. If, at first sight, in the immediate experience, the «social» is produced by the interactions that individuals decide, in one way or another, to establish between them, the inclusion of these interactions in a space-time frame, which enables their reproduction, gives them an ability for sedimentation in what we call history, and therefore determines their relative autonomy by reference to the individual actors themselves" (p. 119).

For Javeau (1998), society is produced and reproduced by social interactions, framed within the context of social relations structures and historical frameworks. The author sustains that "The production of the social from daily interactions, routine or otherwise, therefore entails at least three distinct processes: i) the «production» of the social itself [...]; ii) the «reproduction» of the social «such as in itself», that is, the preservation of the forms and contents of social relationships from one generation to another [...]; (iii) the «production» of the transformation inherent in any social formation, through the collective adoption of innovations or through adaptation to changes in the environment" (p. 149).

According to Sallum Jr. (2005),

"This is an attempt to accurately distinguish and articulate theories that focus on different levels of the social order: the micro-level - which refers to individual agents and interactive processes -, the meso-level - which regards movements, associations, groups, formal organisations (workplaces, unions, churches, etc.) and social institutions and the macro-sociological level - which concerns the processes of differentiation, stratification and social integration at the national and global levels (scope which includes relationships that go beyond or cross the national level of corporate society)" (p. 23).

Pires $(2014$, p. 33; 2015) refers to these three levels, which are identified in Table 1, as interaction (micro), group's constitution (meso) and systemic interdependence (macro) - can be briefly defined as intersubjective relationships and between individual acts (micro).

Table 1. Theoretical model of sociological analysis: conceptual scheme

\begin{tabular}{l|l|l|l}
\hline \multicolumn{2}{l|}{} & \multicolumn{1}{c}{ Relational standardisation modes } \\
\cline { 3 - 4 } & $\begin{array}{l}\text { Phatic standardisation } \\
\text { (conditioning) }\end{array}$ & $\begin{array}{l}\text { Normative standardisation } \\
\text { (orientation) }\end{array}$ \\
\hline \multirow{2}{*}{$\begin{array}{l}\text { Types/levels of social } \\
\text { relationships }\end{array}$} & $\begin{array}{l}\text { Systemic interdependence } \\
\text { (macro) }\end{array}$ & Positional systemicity & Institutional systemicity \\
\hline Constitution of groups(meso) & network grouping & Organisational grouping \\
\cline { 2 - 4 } & Interaction (micro) & rational action & interpretive action \\
\hline
\end{tabular}

Source: Pires (2014, p. 32).

The influence of micro, meso and macro levels of social analysis, besides the paradigmatic and methodological complexities, has profound implications and even limitations put forward by several authors. For example, Pyyhtinen 
(2017), claims that "By presupposing that phenomena are placed on two (or three) levels only, the viewpoint not only remains blind to how scales are in fact much more multiple, rich, and messy, but it is also inattentive to how processes, actions, and associations may crisscross various scales as well as how scales are produced in action" (p. 298).

In turn, Fine (2012) argues that "Group life provides a basis by which individuals fit into society and through which social structures shape them. The group establishes and validates meanings that constitute the propriety of action. However, a group is also a community that establishes boundaries and divisions, where inequalities are resisted or reproduced. Groups expand and fracture, both internally and within the wider social system" (p. 173) without forcing the existence of a certain social order, given that "quite complex patterns of social interaction may continue, not because participants share any specific values concerning the broad organization of society, but because their relations are pervaded by less ethereal feelings like trust, and because everyone gets something out of their mundane relationships" (Kurawa, 2012, p. 36).

\section{Conclusion}

It is concluded that the meso-social level is, in some perspectives, mobilised by focusing mainly on the group or the organisation, as an intermediate bridge between the other two levels of analysis (Ferreira \& Serpa, 2017; Zald, 1991).

As for the implications, it may be asserted that the meso level only has heuristic capabilities in interpretating a given social context if the other two levels (micro and macro-social) are not neglected in social analysis (Ferreira \& Serpa, 2017; Hartman, 2017; Javeau, 1998; Pires, 2012b).

\section{Funding}

University of Azores, Interdisciplinary Centre of Social Sciences - CICS.UAc/CICS.NOVA.UAc, UID/SOC/04647/2013, with the financial support of the FCT/MEC through national funds and when applicable co-financing from the FEDER under the PT2020 Partnership Agreement.

\section{Acknowledgments}

We would like to thank to the Reviewers for their comments and suggestions.

\section{References}

Biblioteca do Conhecimento Online (n.d.). What is b-on? Available at https://www.b-on.pt/en/what-is-b-n/. Accessed on January 17, 2019.

Boateng, W. (2013). A sociological overview of knowledge management in macro level health care decision-making. Journal of Sociological Research, 4(2), 135-146. https://doi.org/10.5296/jsr.v4i2.3165

Borup, M., Brown, N., Konrad, K., \& Van Lente, H. (2006). The sociology of expectations in science and technology. Technology Analysis \& Strategic Management, 18(3-4), 285-298. https://doi.org/10.1080/09537320600777002

Ferreira, C. M. (2007). A medicalização dos sanatórios populares. Desafios e formas de um processo social [The medicalisation of popular sanatoria. Challenges and forms of a social process]. $\mathrm{PhD}$ thesis in Sociology, Faculdade de Ciências Sociais e Humanas, Universidade Nova de Lisboa.

Ferreira, C., \& Serpa, S. (2017). Challenges in the teaching of Sociology in higher education. Contributions to a discussion. Societies, 7(4), 30. https://doi.org/10.3390/soc7040030

Fine, G. A. (2012). Group culture and the interaction order: Local Sociology on the meso-level. Annual Review of Sociology, 38(1), 159-179. https://doi.org/10.1146/annurev-soc-071811-145518

Giddens, A. (1997). Sociologia [Sociology]. Lisboa: Fundação Calouste Gulbenkian.

Hartmann, E. (2017). Violence: Constructing an emerging field of Sociology. International Journal of Conflict and Violence, 11, 1-9.

Ibáñez, J. E. R. (1997). De Liliput a Brobdingnag: Nota sobre las relaciones micro-macro en sociología [From Liliput to Brobdingnag: Note on micro-macro relationships in sociology]. Revista Española de Investigaciones Sociológicas, 80, 171-182. https://doi.org/10.2307/40183921

Javeau, C. (1998). Lições de Sociologia [Lessons of Sociology]. Oeiras: Celta Editora.

Kurawa, S. S. (2012). Social order in Sociology: Its reality and elusiveness. Sociology Mind, 2(1), 34-40. https://doi.org/10.4236/sm.2012.21004

Morais, J. V., \& Ratton Jr., J. L. (2005). Gilberto Freyre e a articulação dos níveis micro e macro na sociologia [Gilberto Freyre and the articulation of micro and macro levels in Sociology]. Revista Brasileira de Ciências Sociais, 20(58), 129-144. https://doi.org/10.1590/S0102-69092005000200006

Pires, R. P. (2012a). O problema da ordem [The problem of order]. Sociologia, Problemas e Práticas, 2012(69). 
https://doi.org/10.7458/SPP201269785

Pires, R. P. (2012b). O problema da integração [The problem of integration]. Sociologia, Revista da Faculdade de Letras da Universidade do Porto, XXIV, 55-87.

Pires, R. P. (2014). Modelo teórico de análise sociológica [Theoretical model of sociological analysis]. Sociologia, Problemas e Práticas, 74. https://doi.org/10.7458/SPP2014743199

Pires, R. P. (2015). Modos de explicação [Explanation modes]. Sociologia, Problemas e Práticas, 78, 125-141. https://doi.org/10.7458/SPP2015786687

Pyyhtinen, O. (2017). Matters of scale: Sociology in and for a complex world. Canadian Review of Sociology/Revue Canadienne de Sociologie, 54(3), 297-308. https://doi.org/10.1111/cars.12151

Rocher, G. (1989). Sociologia geral. A acção social. (Vol I) [General Sociology. Social action. (Vol I)]. Lisboa: Editorial Presença.

Sallum Jr., B. (2005). O futuro das Ciências Sociais. A Sociologia em questão [The future of Social Sciences. Sociology in question]. Sociologia, Problemas e Práticas, 48, 19-26.

Sell, C. E. (2016). Max Weber e o átomo da sociologia: Um individualismo metodológico moderado? [Max Weber and the atom of Sociology: A moderate methodological individualism?]. Civitas - Revista de Ciências Sociais, 16(2), 323-347. https://doi.org/10.15448/1984-7289.2016.2.22167

Serpa, S. (2017). Book review: Pensamento sociológico. Uma introdução didática às teorias clássicas [Sociological thought. A didactic introduction to classical theories]. International Journal of Social Science Studies, 5(7), 19-21. https://doi.org/10.11114/ijsss.v5i7.2444

Serpa, S. (2018). A reflection on Sociology of Education. International Journal of Social Science Studies, 6(3), 33. https://doi.org/10.11114/ijsss.v6i3.3013

Serpa, S. N. (2016). Organization as an analytical level for investigation organizational culture. The Social Sciences, 11(13), 3257-3263.

Serpa, S., \& Ferreira, C. M. (2018). Sociological problem and social problem: Contributions to a discussion. Sociology and Anthropology, 6(11), 840-844. https://doi.org/10.13189/sa.2018.061104

Serpa, S., \& Sá, M. J. (2019). Exploring Sociology of Education in the promotion of sustainability literacy in higher education. The Journal of Social Sciences Research, 5(1), 101-116. https://doi.org/10.32861/jssr.51.101.116

Wiley, N. (1988). The micro-macro problem in social theory. Sociological Theory, 6(2), 254. https://doi.org/10.2307/202119

Zald, M. N. (1991). Sociology as a discipline: Quasi-science and quasi-humanities. The American Sociologist, 22(3-4), 165-187. https://doi.org/10.1007/BF02691895

\section{Copyrights}

Copyright for this article is retained by the author(s), with first publication rights granted to the journal.

This is an open-access article distributed under the terms and conditions of the Creative Commons Attribution license which permits unrestricted use, distribution, and reproduction in any medium, provided the original work is properly cited. 